\title{
Hydraulic patronage: A political ecology of the Turkey-Northern
}

\section{Cyprus water pipeline}

\author{
Michael Mason
}

Department of Geography and Environment, London School of Economics and Political Science, Houghton Street, London, WC2A 2AE, UK, Email: m.mason@1se.ac.uk

\begin{abstract}
From a political ecology perspective, I label hydraulic patronage the systemic provision of water resources by a patron state to a client territory. The mega-infrastructure of the TurkeyNorthern Cyprus water pipeline is identified as an example of Turkish hydraulic patronage, combining the centralised determination of volumetric flows with a market-led distribution network configuring water allocation and management in the de facto (internationally unrecognised) state of Northern Cyprus. This patronage articulates a Turkish hydroterritorialisation at odds with an island-wide hydrosocial scaling performed by the Republic of Cyprus. Early opposition to the pipeline from municipalities in Northern Cyprus focused on their loss of rents from the licensing of water extraction, while pro-unification political parties objected to a potential spoiling effect on future peace talks with the Republic of Cyprus. Ecological criticisms of the pipeline from Turkish Cypriot civil society actors stressed the displacement of alternative development pathways, including sustainable water management. Hydraulic patronage highlights the duality of state-making and environmentmaking in the reproduction of contingent sovereignty, which is observable in de facto states and other client territories (e.g. occupied and annexed lands).
\end{abstract}




\section{Introduction}

On 17th October 2015, at a grand opening ceremony on the north coast of Cyprus, Turkish President Recep Tayyip Erdoğan and Turkish Cypriot leader Mustafa Akıncı heralded the arrival of piped freshwater from Turkey. Hailed by Erdoğan as the 'project of the century', the Turkey-Northern Cyprus water pipeline, constructed between 2013 and 2015, transports water from the Anamur River in southern Turkey to the internationally unrecognised 'Turkish Republic of Northern Cyprus' (TRNC). The $107 \mathrm{~km}$ pipeline includes an $80 \mathrm{~km}$ section traversing the sea before reaching the Geçitköy dam and reservoir in Northern Cyprus, from where water is pumped across the territory for domestic and agricultural use: up to 75 million cubic metres (MCM) of water is available annually. The self-declared 'benevolence' of the Turkish supply of piped water to the TRNC prompted heavy scepticism from the Republic of Cyprus, notwithstanding the Turkish representation of the pipeline as a potential conduit for island-wide reconciliation. At the inauguration ceremony Erdoğan declared that "If the Greek Cypriot side encounters issues later on with regard to water, then the water brought to the north via pipelines could be the water of peace" (Deputy Prime Ministry and Ministry of Foreign Affairs, 2015). However, Greek Cypriots viewed the project with suspicion, speculating that the water could even be used as a weapon against them (Fotiadhis, 2014).

In this paper I argue that the water pipeline is a hydraulic technology for wielding and deepening Turkish state influence over the TRNC, whilst also sustaining the de facto statehood of Northern Cyprus. ${ }^{1}$ I term hydraulic patronage this systemic water resourcing by Turkey of its client state, which conjoins hydrological dependence to the already strong fiscal and military reliance of Northern Cyprus on Turkey. ${ }^{2}$ The pipeline mega-infrastructure is a grandiose development gift from Turkey; yet it carries contractual and political conditionalities which are no means accepted uncritically by Turkish Cypriot politicians and 
affected municipalities. Its construction took place against, and arguably responded to, a decade-long decline in Turkish nationalism in Northern Cyprus, such that the symbolic gifting of the pipeline was as geopolitically significant as its material transfer of water. Drawing primarily on 21 semi-structured interviews conducted May-July 2016 - featuring TRNC legislators and other politicians, members of regulatory bodies, and civil society representatives (notably environmental/water engineers, planners and agricultural experts) $)^{3}-$ I examine the material and symbolic politics associated with the Turkish-Northern Cyprus water pipeline as a conduit for state-making and environment-making.

The notion of hydraulic patronage leans into geographical scholarship examining what Harris (2017) labels 'political ecologies of the state', blending political geographic concepts on state power, territoriality and knowledges with political ecology insights on the power-laden properties of state-nature interactions (Dittmer, 2014; Gustafson, 2015; Parenti, 2015; Thierault, 2017). While there are multiple, sometimes conflicting, theories at play in this growing body of work, a common concern is to critique the 'collective fiction' of the state as a unitary subject exercising sovereign power through the control of territory (Kuus \& Agnew, 2008). The political ecology optic throws into focus the entanglement of state forms and practices with the more-then-human materiality of 'nature'; indeed, state authority is often projected and legitimated by the (re)production of socio-natural assemblages (GrundyWarr, Sithirith, \& Li, 2015; Mason \& Khawlie, 2016; Robbins, 2008; Whitehead, Jones, \& Jones, 2007). Hydraulic infrastructures - including large dams, desalination plants and water pipeline networks - are paradigmatic vehicles for the exercise of state power, though often with unanticipated hydrological and political effects (Meehan, 2014; Menga, 2017; Menga \& Swyngedouw, 2018; Swyngedouw, 2015; Williams \& Swyngedouw, 2018). They are implicated in the wider production of what Boelens et al. (2016) term hydrosocial territories - the spatial configurations of human practices, institutions, water flows, hydraulic 
technologies and biophysical elements revolving around the control of water. A central claim in this paper is that the Turkish-Northern Cyprus water pipeline advances a Turkish project of hydro-territorialisation, consolidating Turkish influence over the pathways of politicaleconomic development available to Turkish Cypriots (enhancing thereby the negotiating currency of Turkey in any future island-wide peace negotiations). This hydrosocial rescaling is contested by pro-unification forces in Northern Cyprus and strongly opposed by the Republic of Cyprus, which is recognised by the United Nations Security Council as holding de jure sovereignty over the whole island. Empowered by its European Union (EU) membership, the Republic applies its own island-wide hydro-territorialisation under the EU Water Framework Directive, scaling Cyprus as a single river basin district, even though 23 of the island's 70 major watersheds are located outside its effective control in Northern Cyprus (Water Development Department, 2011, p. 12).

The Turkish-Northern Cyprus water pipeline radically disrupts the hydro-social territoriality constructed by Republic through the Water Framework Directive. As a megainfrastructure gift from Turkey to the TRNC, it alters the material and imaginative relations between Turkish Cypriots, their 'motherland' and the Republic of Cyprus. Yeh (2013) observes, in a study of the Sino-Tibetan relationship, the role of Chinese 'development gifts' as vehicles of state territorialisation, deepening the spatial containment of Tibetans and naturalising their amalgamation with the People's Republic of China. Under the precarious conditions of existence often facing contested territories, such development gifts can reinforce the dependence of a client territory on support from a patron state. At the same time, as shown by critical geopolitical scholarship on the post-Soviet de facto states, external patronage often includes substantial affective work to foster loyalty and shared identity, notably by appeals to ethnic-national affinities with client populations (O’Loughlin, Kolossov, \& Toal, 2014; O’Loughlin, Toal, \& Kolosov, 2016; Toal, 2017). I discuss below 
how Turkish hydraulic nationalism was employed to frame the Turkey-Northern Cyprus pipeline as a symbol of an environment-conquering, neoliberal modernity, generating new flows of water and wealth for Turkish Cypriots.

The next section of the paper provides a theoretical delineation of hydraulic patronage, outlining a political ecology perspective on the use of large water infrastructure by a patron state to exercise extraterritorial power over a client entity - in the empirical case discussed below, the client is a de facto state that, while lacking international recognition, maintains some internal characteristics of statehood, including a government, population and effective control over its territory. The 'contingent sovereignty' of the TRNC includes, I argue, hydro-political vulnerabilities which have allowed Turkish water transfers to be represented as a lifeline for viable statehood: a section on water use in Northern Cyprus outlines those hydraulic imaginaries and governance practices used to justify the massive engineering feat of a water pipeline from Turkey. I then examine the fraught Turkey-TRNC political relations that followed the completion of the pipeline in 2015, in particular Turkish Cypriot opposition to the neoliberal governance conditionalities designed by Turkey to 'incentivise' the efficient allocation of water in Northern Cyprus, which disrupted local forms of rent-seeking over water, displaced alternative options for water management and were seen by some as a possible obstacle to the reunification of the island. Challenges to the pipeline were not coordinated and sustained enough to prevent the application of Turkish hydraulic control over its client state, although the pipeline project has not, as yet, boosted Turkish nationalist sentiment in Northern Cyprus. The conclusion offers suggestions for further theoretical exploration and broader applicability of the concept of hydraulic patronage. 


\section{Water infrastructure, state-making and hydraulic patronage}

The development of large-scale water infrastructure is a long-established means for states to create and transform hydrosocial territories. At the heart of state-led hydroterritorialisation processes is the (re)production of scalar configurations seeking command over hydraulic flows in order to allocate resources and exercise sovereign power. Hydrosocial territories are spatially bound socio-natures enmeshed in other scalar relations (political, economic, cultural and ecological), which support, overlap or contest state imaginaries and materialisations of hydraulic control (Boelens et al., 2016, p. 5). Different scalar plans and projections of hydrosocial territories may, if institutionalised, transfigure livelihood opportunities, property structures, political representation and socionatural development. There are clear parallels between this understanding of scalar politics and the large body of work by geographers on rescaling, most obviously those interventions attuned to the ways in which scalar configurations of water significantly shape political-ecological processes (e.g., Clarke-Sather, 2017; Feitelson \& Fischhendler, 2009; Harris \& Alatout, 2010; Johnson, 2015; Sneddon \& Fox, 2006; Swyngedouw, 2007).

Across the eastern Mediterranean, and particularly since the 1950s, state-led hydrosocial scalings have drawn on discourses of development, modernisation and nationalism to justify the construction of large hydraulic infrastructures (Harris \& Alatout, 2010; Morag, 2001; Pyla, 2013). Nowhere is this more evident than Turkey, where the 'hydraulic mission' of water resources development is ostensibly informed by ambitious goals for hydropower generation and the expansion of irrigated agricultural lands, yet at the same time charged politically by a drive to extend state authority and deepen national unity (Conker, 2018; Harris, 2012; Sayan, 2016). Under the centralising direction of the State Hydraulic Works (DSI - Devlet Su İşleri), established in 1954, Turkey has pursued an unyielding territorial consolidation of water resources, rescaling domestic and regional 
dynamics of power. For example, the massive Southeastern Anatolia Project (GAP Güneydoğu Anadolu Projesi), planned ultimately to comprise 22 dams and 19 hydroelectric power plants along the Euphrates and Tigris rivers, underpins a declaration of Turkish (water) sovereignty asserted internally against a Kurdish-majority regional population, and also externally against the downstream volumetric claims of Syria and Iraq (Eder \& Çarkoglu, 2001; Harris, 2012; Harris \& Alatout, 2010).

Turkish hydraulic development, as manifest in hundreds of infrastructure projects, remains wedded to modernist imaginaries and materialities framed as a national conquest of unruly water flows. There is historic continuity with the idea of a modern, secular Turkey fostered, since the foundation of the republic, by a Kemalist political ideology: this utilised the symbolic and material appropriation of territory to forge a forward-looking national identity, yet one unsparing in its treatment of recalcitrant regions and populations (Harris, 2008; Üngör, 2011). The state-making and environment-making of Turkish hydroterritorialisation is of course also inflected by the variegated, evolving settings of politicaleconomic governance in Turkey; most recently the emergence of an 'authoritarian neoliberalism' (Tansel, 2018) defining the period in office of the Justice and Development Party (AKP) and reinforced, following the failed 2016 coup, by the shift in 2018 to a presidential system with sweeping executive powers. Authoritarian neoliberalism inherits the strong market-based macroeconomic programme embraced first by the Özal administration in the 1980s, which rolled out its privatisation model to the water sector, allowing private companies to construct, operate and manage water infrastructure (Harris \& Işlar, 2013; Kibaroglu, Baskan, \& Alp, 2009). The rescaling of water governance to increase private sector involvement and embrace market-based instruments resembles environmental iterations of neoliberalism in many other countries (Bakker, 2013; Cohen \& McCarthy, 2015), and this ideology of economic liberalisation continues to inform AKP political 
ideology. However, the authoritarian turn of the party heavily qualifies its openness to private capital. Political recentralisation under successive AKP administrations has facilitated the steering of private sector gains towards pro-government businesses, especially through public procurement and public-private partnerships. In the water sector, executive recentralisation under DSI and the Ministry of Forestry and Water Affairs has reduced the water management responsibilities previously devolved to municipalities and local irrigation associations (Harris \& Işlar, 2013, pp. 57-58). I address below how Turkey's neoliberal prescriptions for the water pipeline to Northern Cyprus overturned the decentralised norms of water decisionmaking under the Turkish Cypriot government.

The Turkish hydro-territorialisation advanced by the water pipeline also clashes and competes with the hydro-territorialisation of the Republic of Cyprus. Following independence in 1960, water infrastructure development was a lodestone for the statebuilding of the Republic of Cyprus as a binational entity, as promoted and funded by the United Nations (Pyla \& Phokaides, 2018). The prioritisation of irrigation-intensive agriculture as an economic development strategy triggered extensive dam and reservoir construction, which continued in the face of sectarian conflict and the withdrawal of the Turkish Cypriots into self-governing enclaves, until the Turkish military invasion in 1974 sanctioned a 'Turkish Federated State of Cyprus', proclaiming its independence nine years later as the TRNC. ${ }^{4}$ Since the geographical partition of Cyprus in 1974, water on the island has become securitised insofar as rising demand and falling availability from natural sources are seen to threaten the stable (re)production of statehood of both the Republic of Cyprus and Northern Cyprus. The domestic hydrosocial territories of the rival administrations are exclusive and antagonistic, despite shared groundwater reservoirs and other cross-island water exchanges (Zikos \& Roggero, 2013; Zikos, Sorman, \& Lau, 2015). The Republic has sought water security through engineering-led water management: since the 1990s four 
permanent desalination plants have been constructed, and a fifth commissioned, with the goal of producing $30 \%$ of domestic supply by 2020 . A major water transfer system, the Southern Conveyor Project, has also been completed to support the agricultural and urban development of the southern coastal region (Thrasyvoulou, Patsalosavvis, \& Zafirakou, 2016).

Membership of the EU has empowered the hydro-territorialisation of the Republic, legitimating its scalar construction of the whole island as a 'River Basin District' under the EU Water Framework Directive (Water Development Department, 2011). While the 2003 Accession Treaty granting EU membership to the Republic of Cyprus acknowledges that EU law (the acquis communautaire) is suspended in the northern part of the island, it also recognises the Republic's sovereignty over the entire island (Kyris, 2018, p. 435). The river basin scaling of the Water Framework Directive articulates a territorialisation that appeals to 'natural' morphological boundaries, often concealing therefore the political interests favoured by its provisions (Johnson, 2015; Thiel, 2015). For the Cyprus River Basin District, unlike most other river basins in the EU, the hydrological boundaries neatly correspond with the sovereignty over freshwater resources accorded the Republic of Cyprus by the international community, casting its hydro-territorialisation as both ecologically rational and legally definitive. As noted in the next section, EU assistance to Northern Cyprus on water management rules out any prospect of sovereign statehood for the TRNC, instead preparing the territory for alignment with the river basin scaling by the Republic of Cyprus of the Water Framework Directive. The Turkey-Northern Cyprus water pipeline radically disrupts this hydrosocial territoriality, bypassing the island-bounded geomorphology through artificial inter-basin flows and ignoring the sovereign claims of the Republic over water bodies in the north.

I define hydraulic patronage as the provision of water resources by a patron state to a client territory, which may be a de facto state or other territorial entity dependent on, and/or 
controlled by, an external sovereign (e.g. occupied and annexed lands). The contingent statehood of the TRNC relies heavily on Turkish military and financial backing, such that Turkey is deemed by international legal bodies to exercise effective overall control over Northern Cyprus and is thereby subject to norms of state responsibility (e.g. European Court of Human Rights, 2001). ${ }^{5}$ Hydraulic patronage, as a series of material and symbolic practices, projects power from the patron state, embedding and embodying water resource transfers in a wider transformation of geopolitical spaces and ecologies. State-led efforts to control hydraulic flows may be viewed through the Foucauldian lens of an aleatory political ecology, which maps different technologies of state power according to their centripetal (juridicaldisciplinary) and centrifugal (governmental) forms (Alatout, 2013; Clarke-Sather, 2017). From this conceptual register, the Turkish hydro-territorialisation delivered by the TurkeyNorthern Cyprus pipeline could be interpreted as combining the centralised (centripetal) determination of volumetric flows with the networked (centrifugal) effects of a distributive water infrastructure set up in Northern Cyprus: their complementary operation normalises a Turkish state nature which seemingly conquers the hydro-climatic risks of water shortage for Turkish Cypriots through the technological command of inter-basin supplies and price-based demand management in Northern Cyprus (cf. Clarke-Sather, 2017, p. 94). While important insights can be gained from this perspective on the operation of general logics of state power within a national territory, I argue that hydraulic patronage names a distinctive form of extraterritorial capacity for state-making and environment-making; more precisely, an asymmetric exercise of hydraulic power by a state over a dependent territory. In the case of the Turkey-Northern Cyprus water pipeline, as detailed below, there are good reasons to categorise the Turkish patronage as a projection of extraterritorial authoritarian power (Glasius, 2018). Rather than contradicting this authoritarian steering, the systemic privileging by Turkey of certain market-based mechanisms in distributing pipeline (and non-pipeline) 
water across Northern Cyprus is consistent with the authoritarian liberalism propagated by the ruling AKP government in Ankara (Tansel, 2018). Similarly, the 'benevolence' of the gifting of the pipeline infrastructure by Turkey to Northern Cyprus is not incompatible with patronage as a form of material and symbolic domination over a client territory (Yeh, 2013).

Hydraulic patronage promotes state-making and environment-making through the creation of a compliant hydrosocial territory, but reveals in its exercise the deeply unequal terms of geopolitical exchange between the two. Surveying other efforts to normalise the Turkish control over Northern Cyprus through geographical change - tourism developments, the conversion of churches to mosques, the renaming of villages - Navaro-Yashin (2010) and Ram (2015) observe the continuous resurfacing of the territory's exceptional governance. Below I argue that the cascading political and ecological effects of Turkish hydraulic patronage in Northern Cyprus encountered resistance, ironically unsettling some of the domestic structures of clientelism which have, for sections of the local population, legitimated Turkish control of the territory. In particular, the neoliberal water governance prescriptions accompanying the completion of the pipeline challenged sources of local authority (and water-enabled elite wealth), while the ecological rationality of the pipeline faced interrogation by civil society actors. Both sources of discontent are connected to what Lacher \& Kaymak (2005) identify as the implosion of Turkish nationalism in Northern Cyprus, triggered by financial crises from 2000-2001 but reflecting also systemic weaknesses in the political-economic foundations of the TRNC. For the Turkish state, the water pipeline provided an opportunity to revive nationalist sentiment in Northern Cyprus and further institutionalise extraterritorial control. In the next section of the paper, I set out the geopolitical context and political-institutional effects of this hydraulic patronage. 


\section{The Turkey-Northern Cyprus pipeline: water resourcing a client state}

Since its creation, an important source of political legitimacy for the Republic of Cyprus has been hydraulic development in the face of perceived water scarcity, mirroring British colonial concerns about an intemperate island climate and the governing need to reverse perceived land degradation and unproductive water use (Harris, 2007). The international negotiations on an independent Cyprus featured discussions on large-scale water transfers from Turkey. Nihat Erim, an architect of the 1959 London and Zurich Agreements which prefigured the new constitution, recalled in his memoirs British proposals to construct an underwater pipeline from Turkey to the island, pitching the planned infrastructure as a means of ensuring that Turkish interests would continue to be recognised by an independent Cyprus (Erim, 1975, pp. 37-38). While this did not happen, and the Republic over time undertook the hydraulic development already noted, the north of the island under Turkish Cypriot control faced increasing water scarcity, constraining an economy largely dependent on agriculture (Morvaridi, 1993). Until the Turkey-Northern Cyprus pipeline, over 90\% of annual freshwater resources were sourced from groundwater reservoirs, with water extraction routinely exceeding the natural recharge of these aquifers. In 1997 DSI undertook for the Turkish Cypriot government a major water assessment of the western Güzelyurt region, where most irrigated crops are cultivated (notably citrus fruit production): it found uncontrolled irrigation and inefficient water extraction, with high levels of salt contamination due to saltwater intrusion of the depleted coastal aquifer (Elkiran \& Turkman, 2008, p. 241). These water deficiency concerns prompted a bulk water transfer initiative. Between 1998 and 2002 a total of 4.1 MCM of water was transported from by Turkey by ship-towed large water bags, but this method was abandoned as it fell short of a supply target of $5 \mathrm{MCM} / \mathrm{year}$ (Elkiran \& Ergil, 2006, p. 1672). By 2007 the three coastal aquifers in Northern Cyprus were 
all reported to have high saline content, while the Central and Western Mesaoria Aquifer, shared with the Republic, was heavily depleted (Elkiran \& Turkman, 2008).

Between 1999 and 2007 Turkish feasibility studies on the water pipeline mapped out current and future water demand in Northern Cyprus and explored technical options for water transfer by a suspended subsurface pipeline: the first design tender was issued in 2005 . Construction of the $107 \mathrm{~km}$ pipeline took place 2013-2015, funded by a grant from the Turkish Aid Commission and managed by DSI, utilising novel technology (high density polyethylene) for the $80 \mathrm{~km}$ section of the pipeline traversing the sea between Anamur, southern Turkey and the north Cyprus coast. The Anamur River, the source basin for the pipeline, was subject to the dam-led hydrosocial territorialisation producing DSI-engineered waterscapes all over Turkey. High in the Taurus Mountains, the Alaköprü Dam captures a tenth of the annual flow of the river and, while supplying the bulk of its water to Northern Cyprus, it also generates hydroelectric power and boosts irrigated agriculture in the region, although the flooding for the dam reservoir in 2015 led to the displacement and resettlement of three villages. Water is transferred, mainly gravity-led, from the Alaköprü Dam through the pipeline to the Gecitköy Dam, Northern Cyprus, which has a reservoir capacity of 26 million MCM. The Turkish government grant for the pipeline project funded the construction of $480 \mathrm{~km}$ of mains piping, to distribute water from the reservoir throughout Northern Cyprus. At Güzelyali Station, near Gecitköy Dam, DSI maintains centralised management over volumetric capacity and water flows in the Turkish Cypriot territory, remotely directing taps and control points across the distribution network. It has trained ten Turkish Cypriot water engineers to build pipeline-related technical capacity on the island (interviewee 7).

The legal framework governing the water pipeline is established by three intergovernmental treaties between the Republic of Turkey and the TRNC - a 2010 framework treaty, a 2012 protocol on economic and financial cooperation, and a 2016 
intergovernmental agreement regarding the delivery and management of water. ${ }^{6}$ Under the 2016 agreement, which commits the parties to the piped transfer of water for at least 30 years, Turkey accepts the obligation to deliver annually $75 \mathrm{MCM}$, but not less than the water needs of the TRNC (Article 5). According to Turkish Cypriot officials, in 2016 annual water demand of 105-110 MCM (of which $80 \%$ was for agricultural use) exceeded supply by up to a third, so the new water more than meets the identified volumetric deficit (interviewees $3 \&$ 6). However, alongside the gifting of the pipeline to Northern Cyprus, Turkey insisted on the privatisation of water management and distribution in the territory. The pipeline agreements commit the TRNC to guaranteed purchases of Turkish-piped water and the adoption of water pricing. According to a Turkish state official, this was necessary to curb over-use: "Water pricing will lead to more efficient water use on the island: until now, municipalities are inefficient in their allocation of water" (interviewee 1). A Turkish water management company, appointed by tender, is granted authority under the 2016 agreement to establish a tariff system for water differentiated by sectoral users according to the principle of 'user pays' as applied through the licensing and metering of water consumption. There is also a nodiscrimination clause protecting the managing company from new tax or other financial burdens, and entitling it to reductions, exceptions or exemptions applied across the territory by fiscal or other regulatory changes (2016 Agreement, Article 16).

While publicly committed to addressing the water needs of Turkish Cypriots, the pipeline-related agreements articulate a Turkish hydro-territorialisation in Northern Cyprus. As noted by Yeh in a Chinese-Tibetan context, patronage as a development gift performs a state effect of involuntary recognition of the patron by the client territory: gifting projects the benevolence of the patron, whilst masking the impossibility of refusal (2013, pp. 14-17). The market-based contractual arrangements and water pricing applied are consistent with privatisation models in Turkey and, in the strong political direction of private sector 
responsibilities; they also display the authoritarian tenor of AKP neoliberalism. If the extraterritorial water resourcing provided by Turkey justifies the general classification of hydraulic patronage, Turkish authoritarian liberalism shapes its particular application in Northern Cyprus. This state-led combination of executive control and private sector discipline to deliver hydraulic patronage is evident, I claim, from five political-institutional effects: (i) the centralisation of water control given to the private management contractor; (ii) the constraints placed on the regulatory autonomy of the host government; (iii) the active bypassing of countervailing (EU) water governance interventions; (iv) the constraint on Northern Cyprus of long-term purchasing guarantees for pipeline-supplied water; and (v) the symbolic and material imposition of a Turkish state nature.

In the first place, the pipeline treaties give a private management company centralised control over the allocation of pipeline and non-pipeline water in Northern Cyprus, subject to the annual volumetric transfers effectively determined by Turkey. Prior to the agreements, the allocation and management of water in the north of the island was highly decentralised, vesting governance authority in municipalities who licensed water extraction, distribution and payments. In the absence of an independent water regulator, municipalities used water bills as a major revenue-raising vehicle, enriching favoured political constituencies at the cost of unregulated and non-transparent water use (interviewee 6). Article 8 of the 2016 Turkey-TRNC Agreement removes from municipalities, and assigns to the managing company, relevant water infrastructure, water management responsibilities and authority over new water permits/licenses. This right has an expansionist spatial logic, for water permits and licenses issued outside the coverage of the pipeline network are cancelled when the network reaches those areas; and the managing company is charged with making investments, estimated at 1.6 billion Turkish lira (interviewee 13), to extend further the distribution network. A purchase guarantee clause authorises water use charges against 
municipalities even if they do not recognise the agreement on the delivery and management of pipeline water: as noted in the next section, after initial opposition, all municipalities eventually endorsed it. Although Turkish Cypriot politicians supporting the pipeline insist that this centralised water management by a private management company is "a negotiated outcome between Turkey and the TRNC" (interviewee 3), it has facilitated a dramatic switch of governance authority away from local municipalities.

Secondly, the market-led norms promulgated by the pipeline agreements to incentivise the efficient usage of water in Northern Cyprus are underwritten by controls constraining the regulatory discretion of the host state. From a Turkish government perspective, in line with the neoliberal reforms applied to its domestic water sector, this is publicly framed as 'good governance' rather than external interference: "privatisation is not a political choice but a necessity to improve governance" (interviewee 1). The TRNC government is charged with preventing unlicensed water use, thereby protecting the near monopoly control of new volumetric flows enjoyed by the private managing company. Furthermore, the water office of the TRNC Ministry of Agriculture and Natural Resources recognised even by Turkish Cypriot administrators as weak and under-resourced (interviewee 7) - is bypassed as principal regulator of the new privatised water sector. The water pipeline treaties authorise the creation of an independent regulatory committee, based in Northern Cyprus, with representatives of Turkey and the TRNC, though this is charged with supervising the implementation of the agreements rather than developing a monitoring and enforcement role. Membership of the committee, according to the 2016 agreement, comprises three members from the TRNC and two from Turkey. As any decision requires the agreement of four members, Turkey can veto any attempts by the Turkish Cypriot government to encroach on the governance authority of the private management company. 
Thirdly, the pipeline agreements institutionalise water governance arrangements that pull the TRNC away from EU influence, as manifest in its financing of water supply and management initiatives in the north. EU assistance to Northern Cyprus is designed to prepare the territory for alignment with the acquis without working officially with (and therefore recognising) the TRNC government, which nevertheless implemented an EU-consistent environmental law in 2012 and also drafted a water law modelled on the Water Framework Directive (interviewees $11 \& 12$ ). The EU has also supported Turkish Cypriot water needs in Nicosia, co-funding with the Republic of Cyprus a new wastewater treatment plant legally sanctioned by a 1978 agreement on a joint sewerage system between the two mayors of Nicosia. While receptive to the whole-island hydro-territorialisation - a post-unification water imaginary - anticipated by EU assistance to Northern Cyprus, the Turkish Cypriot state has also grown frustrated at Greek Cypriot steering of EU interventions on the island (Kyris, 2018, pp. 435-438), compounded by its perception that the Republic has undermined recent peace negotiations (interviewee 16). Turkey has in turn actively hampered EU water projects in the north, notably an EU-funded seawater desalination plant in Sirianokhori, the construction of which had to be abandoned in 2011 after access restrictions imposed by a nearby Turkish military camp (European Commission, 2012). This cancellation was not lamented by the pro-Turkish TRNC government at the time, a National Unity Party majority administration (2009-2013) aware of the impending construction of the water pipeline: "the National Unity Party cancelled feasibility studies on alternative water sources, stating that these were no longer needed as water would come from Turkey" (interviewee 3). By delivering a Turkish-driven hydro-territorialisation, which entrenches recognition of the de facto state, the pipeline has displaced from the north the island-wide hydrosocial scaling projected and promoted by the EU. It is instructive that European Commission 
representatives in Northern Cyprus interviewed in 2016 reported on not being consulted or even informed by the Turkish government about the pipeline project (interviewees $11 \& 12$ ).

The pipeline agreements, fourthly, concretise a long-term economic dependency between Northern Cyprus and Turkey insofar as the former is committed to purchasing increasing amounts of water (interviewee 17): at the same time, the privatisation of delivery and management services is expected to exercise market discipline on the Turkish Cypriots: "there is a non-payment culture: they will learn the cost of water" (interviewee 1). This is consistent with the application of other privatisations and austerity measures conditioning annual Turkish financial transfers (loans and grants) to Northern Cyprus since 2010. The 2016-18 Structural Transformation Programme agreed between the two governments was framed as the most comprehensive reform package in the history of the northern Cypriot state, with financial support for infrastructure investments, public sector restructuring and measures to reduce the territory's fiscal dependence on Turkey (Turkish Republic of Northern Cyprus Government, 2016). However, the Turkish lira is the operating currency in Northern Cyprus, and the country is heavily reliant on Turkish imports priced in foreign currency, so remains economically vulnerable to a fluctuating lira. Through the long-term purchasing commitments in the pipeline agreements, the TRNC is bound as a client territory to Turkish economic policy, expected to pay its way for the development benefits of a modern water infrastructure.

Lastly, the Turkey-Northern Cyprus pipeline builds a Turkish state nature; that is to say, a particular field of state power in which socio-natural forms are moulded by a sovereign project of modern hydraulic development and Turkish nation-building. As a technological asssemblage creating new capacities and ecologies, it reconstitutes what Toal terms the geopolitical condition: the ways in which geopolitical relations are experienced, understood and practiced (2017, p. 13). The pipeline deepens the presence of Turkish statecraft in 
Northern Cyprus, locking in particular spatialities and temporalities of governance for the client state. According to Turkish state officials, the pipeline is future-proofed, dissipating the risks of water shortage previously faced by Turkish Cypriots: approximately half the initial pipeline allocation is for agricultural use and half for drinking water, with an increasing proportion to be supplied as drinking water if expected population growth occurs in Northern Cyprus, including continuing immigration from Turkey. There is also a calm assurance that the pipeline supply is resilient to climate change impacts (interviewees $1 \& 9$ ), notably more irregular precipitation and greater evaporation as projected both for the Turkish Mediterranean coast - including the Anamur River watershed (the source for pipeline water) - and also Cyprus (Cook et al., 2016; Demircan et al., 2017; Zachariadis, 2016). Indeed, by providing surplus water to Northern Cyprus, DSI officials argue that the pipeline will reduce extraction demands on the island's depleted aquifers, aiding their natural recharging and recovery (interviewee 9). The treatment of climate change impacts as negligible here is consistent with Turkey hydraulic nationalism: climate change considerations have not significantly constrained Turkish water and agricultural development (Turhan et al., 2016). As I argue in the next section, Turkish Cypriot environmentalists have drawn on climate change-related concerns to charge the pipeline mega-infrastructure as an ecologically flawed model of hydraulic domination.

Hydraulic patronage, as conveyed by the Turkey-Northern Cyprus pipeline, effects a hydrosocial territorialisation in Northern Cyprus that, while formally outside Turkish sovereign authority, institutionalises Turkish governing influence over the allocation and management of water. This conjoins the centralised determination of volumetric transfers and water purchase guarantees with the decentralised discipline of unit pricing imposed on water users by a private management company. The pipeline treaties, which as bilateral agreements perform statehood for the TRNC in their legal recognition of the latter, express publicly a 
governance arrangement reached by consent between both parties, affording Northern Cyprus the benefits of long-term water resourcing. This political-legal construction masks the asymmetric projection of Turkish neoliberalism, as characterised above. While the hydraulic patronage in this instance is certainly transformative, I argue in the next section that it is not necessarily determinative in the last instance of water governance in Northern Cyprus. Political relations between Turkey and the TRNC are complex, shifting with changes in governing parties (on the island) and practices. The water privatisation introduced to Northern Cyprus through the pipeline agreements has disrupted structures of domestic clientelism previously centred on unregulated water extraction and non-transparent water licensing, sparking objections from certain elite groups; but this privatisation has also attracted criticism from civil society groups objecting to the environmental and developmental constraints it imposes on Turkish Cypriots.

\section{Spillovers of patronage: Political-ecological effects of the pipeline}

Hydraulic infrastructures allow states to rescale hydrosocial territory, assembling human and non-human elements around a geopolitical ordering of hydrological flows. Under Turkey's modernist imaginary of hydraulic domination, river basins are physically transformed by mega-infrastructure projects, their 'natural' flows captured and channelled for economic development and territorial integration. The inter-basin water resourcing of Northern Cyprus from the Anamur River, southern Turkey, is justified by a nationalist hydroterritorialisation. As a means of forging a shared Turkish identity, hydraulic patronage supplements the cultural geopolitical effects performed by other Turkish transfers to the de facto state (e.g. military protection, financial transfers and Turkish immigration). There are parallels here with the nation-building efforts accompanying Russian patronage of post- 
Soviet de facto states (O’Loughlin, Kolossov, \& Toal, 2014; O’Loughlin, Toal, \& Kolosov, 2016). At the same time, however, the Turkish water pipeline on Northern Cyprus has deeply transformative material and affective impacts, generating 'hydrosocial spillovers' that have disrupted clientelistic practices and geopolitical identities within the territory. For Turkey the pipeline underpins its role as an ethno-guarantor for the TRNC, yet the Turkish nationalist framing of the hydro-territorialisation has faced challenges from those in Northern Cyprus who favour an island-wide Cypriot identity. And the nature-conquering modernism of the pipeline has drawn an ecologically-informed critique from civil society actors, invoking hydroclimatic discourses marginalised by DSI and other Turkish state actors. I address now these political-ecological effects of the pipeline.

Firstly, the cascading political and hydrological effects of the Turkish pipeline for Northern Cyprus have disrupted the domestic structures of clientelism which characterise its governance. The Turkish Cypriot state was founded on a principle of spatial partition (taksim), which Rauf Denktaş, long-standing Turkish Cypriot leader and first president of the TRNC, saw as engendering an independent state and even integration with Turkey (Byrne, 2000). From the ongoing security and transfer payments provided by Turkey, the TRNC drew internal legitimacy, cultivating Turkish nationalism as the principal source of collective identity for the Turkish Cypriot population. The allocation of generous material benefits (e.g. land, government contracts and loans, secure public sector jobs) benefitted the population, but particularly loyal constituencies, under an unashamed system of domestic patronage labelled an "economy of plunder" by Navaro-Yashin (2012, p. 84) - often overseen by governing coalitions led by the pro-Turkish National Unity Party (UBP). Indeed, the first two water pipeline treaties were negotiated with Turkey by a UBP government (2009-2013), while the UBP supported the tendering process for the privatised water management system for Northern Cyprus. However, as noted above, the neoliberal conditionalities for receiving 
pipeline-delivered water mark a break from the historical pattern of Turkish largess for the TNRC. Initial criticism of the pipeline, levelled by municipal politicians, focused on its disruption of local rental streams derived from the municipal licensing of water (interviewees $3 \&$ 17). As the bodies legally responsible for distributing and in some cases treating water, the municipalities in Northern Cyprus used water billing as a major source of revenue (both official and unofficial), leading to local clientelism and unlicensed extraction (interviewees 1 \& 3). The proprietary network of privatised water distribution accompanying Turkish hydroterritorialisation was therefore resisted by municipalities anticipating a significant loss of control and revenues (interviewee 17). However, this opposition was not enduring: all municipalities were eventually induced to support the pipeline, not only because purchase guarantees in the pipeline agreements heavily restricted them from operating outside the new distributive network, but also because they were persuaded that pipeline-generated investments in water infrastructure would generate material benefits for localities. Already by the end of 2015, expectations of a major expansion in irrigated agricultural land and a jump in tourism investment (e.g. from hotels spared water purification costs from the supply of drinkable Turkish water) were associated with a reported tripling in land prices (North Cyprus News, 2015).

Secondly, there were geopolitical challenges to the pipeline over its unsettling effect on the potential for the reunification of the island. In research interviews, former ministers from the Republican Turkish Party (CTP) coalition in charge of the TRNC government during the construction of the pipeline (2013-2015) expressed dissatisfaction with the pipeline agreements negotiated by the previous National Unity Party administration; and a short-term (July 2015-April 2016) CTP-UBP coalition actually collapsed because of disagreements over the 2016 treaty being negotiated with Turkey on the delivery and management of pipeline water (interviewees 4 \& 5). The social democratic CTP has long 
promoted island-wide reunification: CTP leader Mehmet Ali Talat was the first TRNC President (2005-2010) to support a single federated state for Cyprus. Objections to the Turkish-TRNC pipeline agreements from the CTP highlighted the loss of control for Northern Cyprus over the management of the water to the Turkish Department of Water Management, with governance authority further diluted by the transfer of delivery responsibilities to the private sector contractor; though the CTP was split on the merits of privatisation as a policy tool in the water sector (interviewee 17). Other left-leaning political parties in Northern Cyprus (e.g. New Cyprus Party, People's Party, Peace and Democracy Party, Social Democratic Party) raised objections to the nature of Turkish control over water governance locked-in by the pipeline agreements and infrastructure (interviewees 13,14 \& 21). This opposition is symptomatic of the growing presence of TRNC politicians, generally outside core patronage structures, opposing greater Turkish influence over Northern Cyprus. The infrastructural 'gift' of the pipeline has, by its unconcealed circulation of Turkish water governance norms, ironically offered a rallying point for those rejecting Turkish tutelage. Indeed, growing support for unification reflects a longer-term dilution of Turkish nationalist sentiment in the north, which can be tracked back as a trend to the early 2000s when Turkish Cypriots suffered major economic losses from financial crises and protested on the streets against the political repression of the pro-Turkish regime (Lacher \& Kaymak, 2005; NavaroYashin, 2012, pp. xivx-ix). ${ }^{7}$

Criticisms of the pipeline by left-wing Turkish Cypriot politicians were amplified, thirdly, by ecologically-informed objections from a loosely aligned platform of civil society actors, including the Northern Cyprus engineers association, academics, some agricultural interests (e.g. independent olive farmers) and environmental groups (e.g. Solidarity). While these groups expressed diverse concerns, and were not necessarily opposed to the bulk transfer of water as such, a recurring concern raised in the interviews was the displacement of 
alternative development pathways by a hydro-territorialisation locking Northern Cyprus into a water-intensive future. As noted by a prominent Turkish Cypriot environmentalist, due to the pipeline and its wider infrastructure: "Any other water extraction or production will be prohibited, so it may not be possible to create an alternative" (interviewee 19). The circulation of 'new water' is also seen as modifying the landscapes and watersheds of the Turkish Cypriot territory. From a Turkish perspective, the pipeline marries hydraulic modernisation across the source and recipient regions, producing integrated socio-natures of agricultural intensification and urban development. This, as noted above, is a technocratic water imaginary confidently transgressing the morphological constraints of geographically disconnected watersheds. For the civil society actors opposing the pipeline, its hydrosocial effects are ecologically irrational, in spite of the claim from pipeline supporters that water pricing will promote water conservation and the recovery of depleted island aquifers. Critics argued, instead, that the pipeline will incentivise water-rich agricultural production, which is less resilient to projected regional drying and warming trends associated with climate change. Examples cited included the growing use of non-native rootstock for olive tree planting (in contrast to drought-resistant Cypriot varieties) and proposals to increase water-intensive artichoke production (interviewee 10). Furthermore, the accelerated urban and tourist development expected to accompany the availability of new water across Northern Cyprus is forecast by critics to degrade those rural landscapes still supporting high biological diversity (interviewees $10 \& 19)$.

Lastly, civil society actors raised concerns that the geopolitical governance instituted by the pipeline agreements crowds out island-wide scalings of water planning and management. The pipeline governance, it is argued, turns Northern Cyprus into a client territory subject to contractual rules empowering a monopolistic supplier to allocate water as a private commodity. This is seen as narrowing local water supply options - as with the legal 
prohibition of alternative water production, such as desalination (interviewees $10 \& 14$ ) - and also as blocking off the possibility of realising island-wide hydrosocial territories, notably the river basin management planning applied by Republic of Cyprus through its implementation of the EU Water Framework Directive (interviewees 18 \& 19). EU technical assistance to Northern Cyprus on water management has explored sustainability-led policy options, such as wastewater treatment and climate resilient agriculture, which have largely been ignored by the TRNC government (interviewees $11 \& 12$ ); and in contrast to the open, consultative process of river basin management planning in the Republic of Cyprus, civil society actors interviewed in the north bemoaned the opaque nature of water governance. The water management office in the TRNC government is seen as hampered by patronage-based staffing and unprofessional working practices, while implementation of the pipeline agreements has introduced from Turkey another set of closed bureaucratic practices. DSI and the Turkish Embassy in Lefkoşa (Nicosia) reportedly refused requests from Turkish Cypriot activists for information on water pricing and the tendering process to appoint the private company responsible for managing pipeline-supplied water (interviewees $6,15 \& 19$ ). Thus, despite their representation by Turkey as 'good governance' in the water sector, the pipeline agreements are not viewed by these critics as heralding a new era of public accountability over water allocation and management in Northern Cyprus.

While the pipeline facilitated the exercise of Turkish hydraulic patronage over Northern Cyprus, water resourcing the de facto state at an unprecedented level, this was not uncritically received by the client population. Turkish hydro-territorialisation disrupted local forms of rent-seeking, geopolitical affiliations and alternative water imaginaries. Opposition from left-wing Turkish Cypriot politicians focused on the neoliberal governance prescribed by the Turkey-TRNC pipeline agreements and the geopolitical spoiling effect of the pipeline on the potential for island-wide reunification. A loose platform of civil society groups 
highlighted the displacement of alternative development pathways and also raised ecological concerns over apparent incentives to agricultural intensification and uncontrolled tourism development from the wide availability of Turkish-supplied water. They questioned the neglect of island-wide hydrological considerations, comparing unfavourably the pipelinedriven hydrosocial territory of Northern Cyprus with the scaling of Cyprus as a single River Basin District under the EU Water Framework Directive. These various political challenges to the pipeline in Northern Cyprus were not coordinated and sustained enough to prevent the full implementation of the pipeline agreements negotiated under a pro-Turkish UBP government. However, the purported widespread benefits of the pipeline project have not, as yet, revived Turkish nationalist sentiment in Northern Cyprus: the January 2018 election delivered power to a CTP-led governing coalition wary of Recep Erdoğan's authoritarianism and the promotion by his party of cultural-religious norms perceived as alien by many Turkish Cypriots (e.g. calls for stricter Islamic practices).

\section{Conclusion}

This paper examines the Turkey-Northern Cyprus water pipeline as an exemplar of hydraulic patronage - the systemic provision of water resources by a patron state to a client territory. In the case of the pipeline, the client territory is a de facto (internationally unrecognised) state, though the concept could be applied to examine other dependent territories relying on an external sovereign for the provision of water resources (e.g. occupied and annexed lands). Adopting a political ecology perspective, I argue that hydraulic patronage comprises material and symbolic practices which contribute to the production of what Boelens et al. (2016) label hydrosocial territories - spatial configurations of human practices, institutions, water flows, hydraulic technologies, biophysical elements and socio- 
economic structures revolving around the control of water. The Turkish-Northern Cyprus water pipeline relays a project of Turkish hydro-territorialisation: it engineers centralised control over inter-basin flows between southern Turkey and Northern Cyprus, whilst at the same time configuring a market-led distribution network that lessens the water governance authority of the Turkish Cypriot state. I claim that this particular manifestation of hydraulic patronage expresses ideologically an authoritarian neoliberalism associated with the ruling Justice and Development Party (AKP) in Turkey, whilst also reflecting a long-standing Turkish hydraulic mission, both nationalist and modernist in ambition, to command water flows for the purposes of state-building and economic development. For the de facto state in Northern Cyprus, which relies for its existence on Turkish recognition, security and material support, the 'benevolent gift' of the pipeline and its bulk water transfers creates further dependence, prefiguring a water-intensive development pathway of expanding agricultural production and tourism sector growth.

The Turkish hydro-territorialisation performed by its water pipeline to Northern Cyprus is at odds with an island-wide hydrological scaling articulated by the Republic of Cyprus, whose exclusive sovereignty authority over the island is recognised by the international community and reaffirmed in a number of UN Security Council Resolutions. Empowered by its EU membership, the Republic applies a hydro-territorialisation framed by the Water Framework Directive, scaling Cyprus as a whole River Basin District. The EU actively endorses this island-wide scaling, promoting water management practices in the north consistent with the directive while not officially recognising the de facto state: this is part of a broader EU strategy to create institutional conditions conducive to effective reunification. While the water pipeline is represented by Turkey as a potential conduit for peace, the configuration of a hydrosocial territory aligning to the boundaries of the Turkish Cypriot de facto state - including the state-building effects legally enacted by the pipeline 
treaties between Turkey and the TRNC - radically disrupts the hydrosocial territory constructed by the Republic of Cyprus and the EU. The Turkish-Northern Cyprus hydrosocial territory overrides island-bounded hydrogeological processes and negates the sovereign claims of the Republic over water bodies in the north.

While there was no united or effective opposition to the pipeline in Northern Cyprus, various Turkish Cypriots actors challenged the transformative political-ecological effects of Turkish hydro-territorialisation. Early opposition to the pipeline from Turkish Cypriot municipalities focused on the loss of rents from their licensing of water extraction, while prounification political parties objected to the potentially spoiling effect of the pipeline on future peace talks between Northern Cyprus and the Republic of Cyprus. Ecologically-informed criticisms from various civil society groups pointed to the displacement of alternative water development pathways and a divergence from sustainable water management norms. This highlights the duality of state-making and environment-making in hydraulic patronage; the promotion, in this case, of a Turkish state nature in which landscapes and watersheds are moulded by a performative geopolitical framing (O’Loughlin, Toal, \& Kolosov, 2016, p. 747) of hydraulic domination and nation-building. Environmentalists in Northern Cyprus questioned the ecological rationality of this technologically engineered (modernist) conquest of local hydrological variability and scarcity, claiming that it ignores rather than overcomes future climate change vulnerabilities (e.g. projected reduced discharges in Turkey's Anamur River, the source watershed for the pipeline).

A political ecology lens on the Turkey-Northern Cyprus pipeline reveals new insights on the material and imaginative reproduction of de facto statehood under a patron-client relationship. Further research on the concept of hydraulic patronage could productively examine other situations where a controlling sovereign deploys water infrastructure to support state-building and the national integration of a client territory. This need not entail 
the physical transfer of water from the patron state, as with the Turkey-Northern Cyprus pipeline: it may also involve external support for the exploitation of shared or indigenous water resources. There are parallels to draw, for example, with de facto states and secessionist republics recognised by Russia. In 2011 Russia signed a bilateral cooperation agreement with the 'Republic of Abkhazia' on the rational utilisation and protection of transboundary water bodies, mobilising the state-building effect of substantive and procedural norms found in Russian water cooperation with neighbouring sovereign states (Vinogradov \& Wouters, 2019, p. 478). More pronounced is Russian hydraulic patronage of Crimea following its annexation in 2014, though this support has so far been preoccupied with mitigating the effects of the damming by Ukraine of the North Crimean Canal, which had previously provided up to 80 per cent of the water needs of Crimea. Alongside other emergency measures, the Russian Defence Ministry drilled new wells and constructed new pipelines within Crimea in a concerted effort to supply sufficient freshwater (Global Research, 2015; Vinogradov \& Wouters, 2019, pp. 465-477). Here, hydraulic patronage has become part of an existential struggle to sustain the Crimean Republic as a viable hydrosocial territory.

Hydraulic patronage is also a geopolitical strategy in occupied and annexed territories, where the appropriation and exploitation of indigenous water resources by the controlling sovereign may be used to support settler colonisation; for example, Israeli-constructed water reservoirs and irrigation networks in the occupied Golan Heights (Dajani \& Mason, 2018) and the extraction by Morocco of fossil water to facilitate the development of agro-businesses in the southern part of the occupied Western Sahara (Western Sahara Resource Watch, 2013). In both these cases, hydro-territorialisation by the occupying power, publicly framed as benevolent, advances the de facto annexation of the disputed territory. To be sure, there is recognition in the transboundary water literature that 'cooperative' state actions over water 
flows may coexist with conflict relations (e.g. Mirumachi, 2015; Zeitoun \& Mirumachi, 2008); however, the idea of hydraulic patronage expressly interrogates the state-making and environment-making at work. Similarly, the conceptual difference between hydraulic patronage and numerous other water-based investments and infrastructure developments playing out asymmetrically between state and private actors in the global political economy is that the former highlights a particular political-ecologic dynamic of sovereign power over, and production of, a client territory.

\section{Endnotes}

${ }^{1}$ De facto states are generally acknowledged as territories that have gained de facto independence, but that have also failed to achieve meaningful international recognition (Casperson 2017, p. 11: see also Casperson 2011).

${ }^{2}$ Turkish government foreign aid (grants and loans) to Northern Cyprus was 499.2 million Turkish lira in 2014 and 549.1 million Turkish lira in 2015 (Turkish Republic of Northern Cyprus Government, 2016, p. 6).

${ }^{3}$ The interviews in Northern Cyprus were conducted in May-June 2016 with the assistance of Rebecca Bryant (then LSE) and Mete Hatay (PRIO Cyprus Centre). Anonymised transcripts of the interviews are available from the author. In a follow-up trip to Northern Cyprus in May-June 2017, a number of interviewees and other interested parties responded verbally and in writing to draft research findings.

\footnotetext{
${ }^{4}$ This declaration of statehood was rejected by the international community: see, for example, UN Security Council Resolutions 541 (1983) and 550 (1984).
} 
${ }^{5}$ For Turkish Cypriots, the presence of Turkey in the north of the island is variously described as guardianship, paternal control and dependency (Bryant \& Yakinthou, 2012, pp. $16-19)$.

${ }^{6}$ The key agreements are: the Intergovernmental Framework Treaty Between the Republic of Turkey and the Turkish Republic of Northern Cyprus Regarding Meeting the Water Needs of the Turkish Republic of Northern Cyprus (19 July 2010); the Protocol on Economic and Financial Cooperation Between the Republic of Turkey and the Turkish Republic of Northern Cyprus (4 December 2012); and the Intergovernmental Agreement Between the Republic of Turkey and the Turkish Republic of Northern Cyprus Regarding the Delivery and Management of Water (2 March 2016).

7. Support in the north for reunification has also been encouraged, since 2003 , by the relaxing of movement restrictions to the south and the granting of EU citizenship to Turkish Cypriots.

Acknowledgements: Many thanks to Rebecca Bryant (Utrecht University) and Mete Hatay (from the PRIO Cyprus Centre, Nicosia) for facilitating the field interviews conducted in Northern Cyprus and also to the attendees of a meeting in June 2017 at the Home for Cooperation, Nicosia who gave feedback on draft research findings.

Funding: The field research conducted for this project was financed by the Higher Education Innovation Fund, Research England. 


\section{References}

Alatout, S. (2013). Water scarcity in late modernity. In L. Harris, C. Sneddon, \& J. Goldin (Eds.) Contemporary water governance in the global South: Scarcity, marketization and participation (pp. 101-108), London: Routledge.

Bakker, K. (2013). Neoliberal versus postneoliberal water: Geographies of privatisation and resistance. Annals of the Association of American Geographers, 103(2), 253-260.

Boelens, R., Hoogesteger, J., Swyngedouw, E., Vos, J., \& Wester, P. (2016). Hydrosocial territories: A political ecology perspective. Water International, 41(1), 1-14.

Bryant, R., \& Yakinthou, C. (2012) Cypriot perceptions of Turkey. Istanbul: Turkish Economic and Social Studies Foundation (TESEV).

Byrne, S. (2000). Power politics as usual in Cyprus and Northern Ireland: Divided islands and the roles of external ethno-guarantors. Nationalism and Ethnic Politics, 6(1), 1-23.

Casperson, N. (2011). Unrecognized states: The struggle for sovereignty in the modern international system. Cambridge, UK: Polity.

Casperson, N. (2017) Making peace with de facto states. In M. Riegl, \& B. Doboš (Eds.), Unrecognized states and secession in the $21^{\text {st }}$ Century (pp.11-22). Cham, Switzerland: Springer International.

Clarke-Sather, A. (2017). State power and domestic water provision in semi-arid Northwest China: Towards an aleatory political ecology. Political Geography, 58, 93-103.

Cohen, A., \& McCarthy, J. (2015). Reviewing rescaling: Strengthening the case for environmental considerations. Progress in Human Geography, 39(1), 3-25. 
Cook, B. I., Anchukoritis, K. J., Touchan, R. Meko, D. M., \& Cook, E. R. (2016).

Spatiotemporal drought variability in the Mediterranean over the last 900 years. Journal of Geophysical Research: Atmospheres, 121, 2060-2074.

Conker, A. (2018). Understanding Turkish water nationalism and its role in the hydraulic development of Turkey. Nationalities Papers: The Journal of Nationalism and Ethnicity, 46(5), 877-891.

Dajani, M., \& Mason, M. (2018). Water infrastructure as resistance in the occupied Golan Heights. In F. Menga and E. Swyngedouw (Eds.), Water, technology and the nation-state (pp. 131-146). Abingdon: Routledge.

Demircan, M., Gürkan, H., Eskioğlu, O., Arabaci, H., \& Coşkun, M. (2017). Climate change projections for Turkey: Three models and two scenarios. Turkish Journal of Water Science \& Management, 1(1), 22-43.

Deputy Prime Ministry and Ministry of Foreign Affairs (2015). Erdoğan: Water from Turkey could be water of peace. Lefkoşa, Turkish Republic of Northern Cyprus: Deputy Prime Ministry and Ministry of Foreign Affairs. http://mfa.gov.ct.tr/erdogan-water-from-turkeycould-be-water-of-peace/

Dittmer, J. (2014). Geopolitical assemblages and complexity. Progress in Human Geography, 38(3), 385-401.

Eder, M., \& Çarkoglu, A. (2001). Domestic concerns and the water conflict over the Euphrates-Tigris River Basin. Middle Eastern Studies, 37, 41-71.

Elkiran, G., \& Ergil, M. (2006). The assessment of a water budget of North Cyprus. Building and Environment, 41, 1671-1677. 
Elkiran, G., \& Turkman, A. (2008). Water scarcity impacts on Northern Cyprus and alternative mitigation strategies. In J. Qi, \& K. T. Evered (Eds.), Environmental problems of Central Asia and their economic, social and security impacts (pp. 241-250). Dordrecht: Springer.

Erim, N. (1975). Bildiğim ve Gördüğüm Ölçüler Icinde Kibris (Cyprus as I knew it and saw it). Ankara: Ajans-Turk Matbaaclik Sanayii (in Turkish).

European Commission (2012). Sixth annual report 2011 on the implementation of Community assistance under Council regulation (EC) No 389/2006 of February 2006 establishing an instrument of financial support for encouraging the economic development of the Turkish Cypriot community: COM/2012/0243 final. Brussels: European Commission.

European Court of Human Rights (2001). Case of Cyprus v. Turkey (Application no. 25781/94). Strasbourg, France: ECHR.

Feitelson, E., \& Fischhendler, I. (2009). Spaces of water governance: The case of Israel and its neighbors. Annals of the Association of American Geographers, 99(4), 728-745.

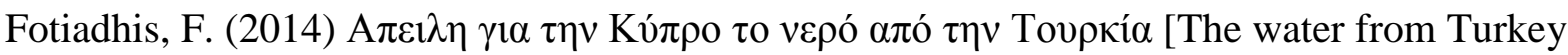
is a threat to Cyprus]. Fileleftheros, 17 November. https://energypress.gr/news/Apeilh-giathn-Kypro-to-nero-apo-thn-Toyrkia

Glasius, M. (2018). The extraterritorial gap. Political Geography, 64, 95-104.

Global Research (2015) Ukraine blockade: New Russian pipelines start supplying fresh water to Crimea. 5 April. Montreal, Canada: Centre for Research on Globalization. https://www.globalresearch.ca/ukraine-blockade-new-russian-pipelines-start-supplying-freshwater-to-crimea/5440800 
Grundy-Warr, C., Sithirith, M., \& Li, Y. M. (2015). Volumes, fluidity and flows: Rethinking the 'nature' of political geography. Political Geography, 45, 93-95.

Gustafson, S. (2015). Maps and contradictions: Urban political ecology and cartographic expertise in southern Appalachia. Geoforum, 60, 143-152.

Harris, S. E. (2007). Colonial forestry and environmental history: British policies in Cyprus, 1878-1960. PhD dissertation, Department of Geography and the Environment. Austin: University of Texas. https://repositories.lib.utexas.edu/handle/2152/3244

Harris, L. (2008). Mordernizing the nation: Postcolonialism, postdevelopmentalism, and ambivalent spaces of difference in southeastern Turkey. Geoforum, 39(5), 1698-1708.

Harris, L. (2012). State as socionatural effect: Variable and emergent geographies of the state in Southeastern Turkey. Comparative Studies of South Asia, Africa and the Middle East, $32(1), 25-39$.

Harris, L. (2017). Political ecologies of the state: Recent interventions and questions going forward. Political Geography, 58, 90-92.

Harris, L. M., \& Alatout, S. (2010). Negotiating hydro-scales, forging states: Comparison of the Tigris/Euphrates and Jordan River basins. Political Geography, 29, 148-156.

Harris, L., \& Işlar, M. (2013). Neoliberalism, nature and changing modalities of environmental governance in contemporary Turkey. In Y. Atasoy (Ed.), Global economic crisis and the politics of diversity (pp. 52-78). London: Palgrave MacMillan.

Johnson, C. (2015). Politics, scale and the EU Water Framework Directive. In E. S. Norman, C. Cook, \& A. Cohen (Eds.), Negotiating water governance: Why the politics of scale matter (pp. 189-205). Farnham, UK: Ashgate. 
Kibaroglu, A., Baskan, A., \& Alp, S. (2009). Neoliberal transitions in hydropower and irrigation water management in Turkey: Main actors and opposition groups. In D. Huitema, \& S. Meijerlink (Eds.), Water policy entrepreneurs: A research companion to water transitions around the globe (pp. 287-303). Cheltenham, UK: Edward Elgar.

Kuus, M., \& Agnew, J. (2008). Theorizing the state geographically: Sovereignty, subjectivity, territoriality. In K. R. Cox. M. Low, \& J. Robinson (Eds.), The Sage Handbook of Political Geography (pp. 205-218). London, UK: Sage Publications.

Kyris, G. (2018). Sovereignty and engagement without recognition: Explaining the failure of conflict resolution in Cyprus. Ethnopolitics, 17(4), 426-442.

Lacher, H., \& Kaymak, E. (2005). Transforming identities: Beyond the politics of nonsettlement in North Cyprus. Mediterranean Politics, 10(2), 147-166,

Mason, M, \& Khawlie, M. (2016). Fluid sovereignty: State-nature relations in the Hasbani Basin, southern Lebanon. Annals of the American Association of Geographers, 106(6), 1344 1359.

Meehan, K. M. (2014). Tool-power: water infrastructure as well springs of state power. Geoforum, 57, 215-224.

Menga, F. (2017). Hydropolis: Reinterpreting the polis in water politics. Political Geography, 60, 100-109.

Menga, F., \& Swyngedouw, E. (2018). States of water. In F. Menga, \& E. Swyngedouw (Eds.), Water, technology and the nation-state (pp. 1-18). Abingdon, UK: Routledge.

Mirumachi, N. (2015). Transboundary water politics in the developing world. Abingdon, UK: Routledge. 
Morag, N. (2001). Water, geopolitics and state building: The case of Israel. Middle Eastern Studies, 37(3), 179-198.

Morvaridi, B. (1993). Agriculture and the environment. In C. H. Dodd (Ed.), The political, social and economic development of Northern Cyprus (pp. 235-251). Huntington, UK: Eothen Press.

Navaro-Yashin, Y. (2010). The materiality of sovereignty: geographical expertise and changing place names in Northern Cyprus. In P. Nikiforos Diamandouros, T. Dragonas, \& Ç Keyder (Eds.), Spatial conceptions of the nation: Modernizing geographies in Greece and Turkey (pp. 127-143). London, UK: I.B. Tauris.

Navaro-Yashin, Y. (2012). The make-believe space: Affective geography in a postwar polity. Durham, NC, USA: Duke University Press.

North Cyprus News (2015). Water project gives huge boost to TRNC land prices, 15 December. http://www.lgcnews.com/water-project-gives-huge-boost-to -trnc-land-prices/ O’Loughlin, J., Kolossov, V., \& Toal, G. (2014). Inside the post-Soviet de facto states: A comparison on attitudes in Abkhazia, Nagorny Karabakh, South Ossetia, and Transnistria. Eurasian Geography and Economics, 55(5), 423-456.

O’Loughlin, J., Toal, G., \& Kolossov, V. (2016). Who identifies with the "Russian World"? Geopolitical attitudes in southeastern Ukraine, Crimea, Abkhazia, South Ossetia, and Transnistria. Eurasian Geography and Economics, 57(6), 745-778.

Parenti, C. (2015). The environment making state: Territory, nature, and value. Antipode, 47, $829-848$. 
Pyla, P. (2013). Introduction: Development histories and the physical landscape of the Eastern Mediterranean. In P. Pyla (Ed.), Landscapes of development: The impact of modernization discourses on the physical environment of the Eastern Mediterranean (pp. 613). Cambridge, USA: Harvard University Press.

Pyla, P., \& Phokaides, P. (2018). An island of dams: Ethnic conflict and the contradictions of statehood in Cyprus. In F. Menga, \& E. Swyngedouw (Eds.), Water, technology and the nation-state (pp. 115-130). Abingdon, UK: Routledge.

Ram, M. (2015). Colonial conquests and the politics of normalization: The case of the Golan Heights and Northern Cyprus. Political Geography, 47, 21-32.

Robbins, P. (2008). The state in political ecology: A postcard to political geography from the field. In K. R. Cox., M. Low, \& J. Robinson (Eds.), The Sage handbook of political geography (pp. 205-218). London, UK: Sage Publications.

Sayan, R. (2016). A political ecology of 'apolitical' water management-lessons learned from Turkish experience. International Journal of Water Governance, 4(14), 1-18.

Sneddon, C. \& Fox, C. (2006). Rethinking transboundary waters: A critical hydropolitics of the Mekong Basin. Political Geography, 25, 181-202.

Swyngedouw, E. (2007). Technonatural revolutions: The scalar politics of Franco's hydrosocial dream for Spain, 1939-1975. Transactions of the Institute of British Geographers, 32(1), 9-28.

Swyngewdouw, E. (2015). Liquid power: Contested hydro-modernities in twentieth-century Spain. Cambridge, USA: MIT Press. 
Tansel, C. B. (2018). Authoritarian neoliberalism and democratic backsliding in Turkey: Beyond the narratives of progress. South European Society and Politics, 23(2), 197-217.

Thiel, A. (2015). Dynamics towards domestic territorialisation of water governance in the EU: The case of southern Spain. In E. S. Norman, C. Cook, \& A. Cohen (Eds.), Negotiating water governance: Why the politics of scale matter (pp. 95-115). Farnham, UK: Ashgate.

Thierault, N. (2017). A forest of dreams: Ontological multiplicity and the fantasies of environmental governance in the Philippines. Political Geography, 58, 114-127.

Thrasyvoulou, P., Patsalosavvis, K, \& Zafirakou, A. (2016). Water supply management in Cyprus under climate uncertainty. Desalination and Water Treatment, 57(5), 2279-2289.

Toal, G. (2017). Near abroad: Putin, the West, and the contest over Ukraine and the Caucasus. New York: Oxford University Press.

Turhan, E, Mazlum, S. C., Şahin, Ü. Şorman, A. H., \& Gündoğan, A. C. (2016). Beyond special circumstances: Climate policy in Turkey 1995-2015. WIREs: Interdisciplinary Reviews on Climate Change, 7(3), 448-460.

Turkish Republic of Northern Cyprus Government (2016). Economic and financial cooperation between the Turkish Republic of Northern Cyprus Government and the Government of the Republic of Turkey in 2016, 2017 and 2018. https://www.ktto.net/wpcontent/uploads/2016/06/2016-2018-Ekonomik-Program_Toplam-82-Sayfa.pdf

Üngör, U. U. (2011). The making of modern Turkey: Nation and state in eastern Anatolia, 1913-1950. New York: Oxford University Press.

Vinogradov, S., \& P. Wouters (2019) Transboundary water cooperation between the Russian Federation and the neighbouring states: legal and institutional frameworks. In S. C. 
McCaffrey, C. Leb, \& R. T. Dennon (Eds.), Research Handbook on International Water Law (pp. 463-478). Cheltenham, UK: Edward Elgar.

Water Development Department (2011). Cyprus River Basin Management Plan, Nicosia: Ministry of Agriculture, Natural Resources and the Environment.

Western Sahara Resource Watch (2013). Dakhla farms depleting underground water resources? Western Sahara Resource Watch. https://wsrw.org/a217x2557

Whitehead, M., Jones, M., \& Jones, R. (2007). Nature of the state: Excavating the political ecologies of the modern state. Oxford, UK: Oxford University Press.

Williams, J., \& Swyngedouw, E. (Eds.) (2018). Tapping the oceans: Seawater desalination and the political ecology of water. Cheltenham, UK: Edward Elgar.

Yeh, E. T. (2013). Taming Tibet: Landscape transformation and the gift of Chinese development. Ithaca, NY: Cornell University Press.

Zachariadis, T. (2016). Climate change in Cyprus: Review of the impacts and outline of an adaptation strategy, Dordrecht, Netherlands: Springer.

Zeitoun, M., \& Mirumachi, N. (2008) Transboundary water interaction I: Reconciling conflict and cooperation. International Environmental Agreements, 8, 297-316.

Zikos, D., \& Roggero, M. (2013). The patronage of thirst: Exploring institutional fit on a divided Cyprus. Ecology and Society, 18(2), 25.

Zikos, D., Şorman, A. H., \& Lau, M. (2015). Beyond water security: Asecuritisation and identity in Cyprus. International Environmental Agreements, 15, 309-326. 